\title{
Impact of globalisation on social psychiatry
}

Marianne Kastrup

From $1^{\text {st }}$ International Congress on Neurobiology and Clinical Psychopharmacology and European

Psychiatric Association Conference on Treatment Guidance

Thessaloniki, Greece. 19-22 November 2009

We are living in a world of rapid change with the most drastic transformations taking place in developing countries. With increasing globalisation billions are forced to face a future so different from life when they grew up that few of their skills are able to assist them with new challenges. Change may result in insecurity, and unpredictability that many people may cope with difficulty. The process of globalisation is not uniform; and some claim that a result hereof is that differences between nations may decrease, but differences between individuals increase. Certain population groups run particular risks during this transformation. Such vulnerable groups may experience the consequences of globalisation as a negative influence on their mental health. From a social psychiatric point of view an important impact of globalisation is the risk of having inadequate access to health care including mental health care. Incentives should be encouraged that result in reducing inequalities among and within groups and nations.

Globalisation is welcoming labor market flexibility, which leads to huge groups of unskilled labourers migrate in search for work. Such populations rarely receive social benefits or protection in case of illness despite the fact that they may have an increased risk of developing mental illness. The process of globalisation is not uniform. In most societies large gender gaps exist regarding access to e.g. education, economic development or adequate health care. Particular attention should be paid to that developmental initiatives are directed towards women thereby closing the gap with men regarding health and education. War and strife are prevalent, and displacement and refugee status are phenomena hitting millions worldwide. Again the distribution is skewed and the poorest parts of the world carry the heaviest burden. The mental health problems

Centre for Transcultural Psychiatry, Psychiatric. Dept. Rigshospitalet, Copenhagen University Hospital, Denmark of these groups need increased attention from a global perspective.

Many ways may be taken to move forward. But psychiatrists globally need to recognize their responsibility in creating awareness and fighting for minimizing the existing disparities.

Published: 22 April 2010

doi:10.1186/1744-859X-9-S1-S55

Cite this article as: Kastrup: Impact of globalisation on social psychiatry. Annals of General Psychiatry 2010 9(Suppl 1):S55.
Submit your next manuscript to BioMed Central and take full advantage of:

- Convenient online submission

- Thorough peer review

- No space constraints or color figure charges

- Immediate publication on acceptance

- Inclusion in PubMed, CAS, Scopus and Google Scholar

- Research which is freely available for redistribution

Submit your manuscript at www.biomedcentral.com/submit
C Biomed Central 